
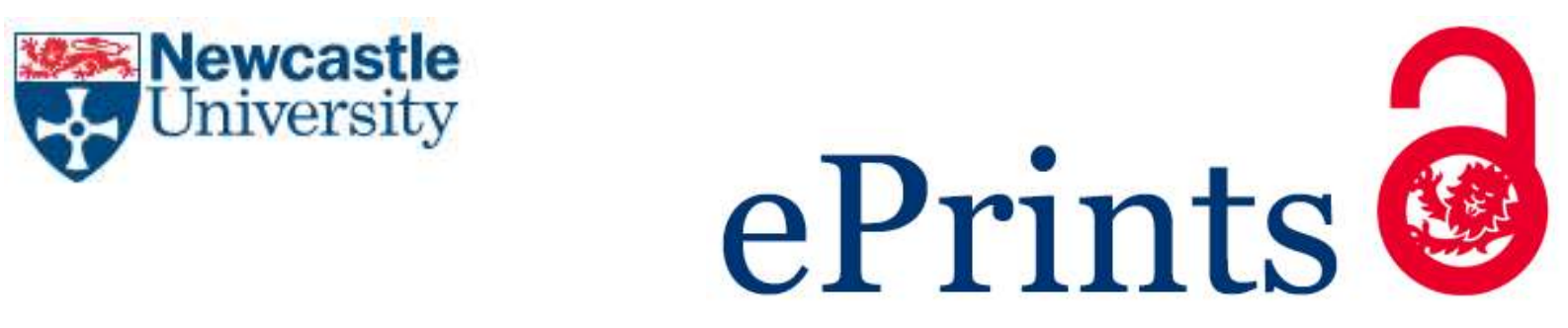

Walker C, Gleaves A. Constructing the caring higher education teacher: a theoretical framework. Teaching and Teacher Education 2016, 54, 65-76. Copyright:

C 2016. This manuscript version is made available under the CC-BY-NC-ND 4.0 license

DOI link to article:

http://dx.doi.org/10.1016/j.tate.2015.11.013

Date deposited:

$21 / 03 / 2017$

Embargo release date:

14 December 2017

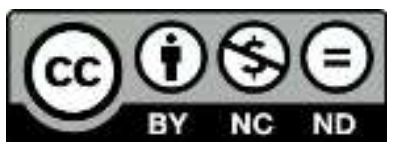

This work is licensed under a

Creative Commons Attribution-NonCommercial-NoDerivatives 4.0 International licence 


\section{Constructing the caring higher education teacher: A theoretical framework}

Caroline Walker, Alan Gleaves

School of Education, Durham University, Leazes Road, Durham, DH11TA, UK

\section{Abstract}

This study seeks to theorize 'the caring teacher' in the context of the higher education environment. The study was carried out from the perspective of the teachers concerned, adopted an inductive interpretive paradigm, and within this, used grounded theory processes and techniques. Emergent categories comprised a relationship at the centre; compelled to care; caring as resistance; and finally, caring as less than. The four categories were combined in the construction of an integrative model to theorize the teacher in higher education who privileges caring within their pedagogy, from the perspective of the higher education teachers themselves.

\section{Introduction}

Good teachers and their teaching matter. According to WalkerGleaves (2010), through the way that they plan their classes, the questioning techniques that they adopt, the level of aspiration and expectation that they engender, and the way that their classes are organized, such teachers appear to make a difference. However, research exploring the impact of particular pedagogical orientations on learners' experiences and achievements frequently undertheorizes the interactions between teachers and students due to the problematic nature of deconstructing the orchestration of skill and judgment in the dynamic environment of the classroom (Dallavis, 2014; Hagenauer \& Volet, 2014a, 2014b). In addition, the literature concerning the links between teachers' interpersonal pedagogic practices on students' learning gains, for example, the manner in which they address and respond to individual students, or the efforts made to understand their personal contexts more precisely, is very limited and equivocal (James \& Pollard, 2011; Kyriakides, Creemers, \& Antoniou, 2009). In addition, there is conflicting research about what specific characteristics of relationship-focused teachers are associated with particular and improved outcomes for learners (Coe, Aloisi, Higgins, \& Major, 2014; Husbands \& Pearce, 2012). Despite conceptual and methodological difficulties, such existing scholarship suggests that many good teachers do exhibit a bounded array of practices and behaviors underpinned by what is termed a relational approach to pedagogy, and an important element of such instructional behaviors appears to be characterized by students and teachers alike as 'caring' teaching (Agne, 1992; Hattie, 2003; Sawatzky, Enns, Ashcroft, Davis, \& Harder, 2009).

Caring teaching in practice appears to comprise two main pedagogic elements - the active fostering of and maintenance of pedagogic relationships above all else, and within these, the privileging of trust, acceptance, diligence and individual attentiveness (Curzon-Hobson, 2002; Docan-Morgan, 2011; Goldstein, 1999; McCormick, O'Connor, Cappella, \& McClowry, 2013; Rudasill, 2011). These pedagogic bonds hold at their centre notions of reciprocity, 
the situation of 'the other' and the significance of reflexivity in responding appropriately (Goldstein, 1999; Noddings, 1986; Rendon, 1994). In turn, caring teachers translate these concepts into coherent bodies of practice whereby they respond to students with timeliness, know students with insight, encounter students with authenticity and treat students with consistency (Artino, Hemmer, \& Durning, 2011; Gay, 2010; Hagenauer \& Volet, 2014b). According to Thayer-Bacon and Bacon (1996): 'teachers who care about their students are remembered, effect change, stimulate growth, and are more likely to be successful at teaching their students' (p. 255).

However, the literature suggests a complex relationship between the multifaceted nature of pedagogic care, raising questions of how and whether teachers classified as caring enact such practices consistently over time, whether all aspects of caring teaching are necessary for being a 'caring teacher' and the impact upon learning outcomes for students (McCormick et al, 2013; Rudasill, 2011). Although there are several studies that examine first-hand teacher narratives of pedagogic care (Barber, 2002; DocanMorgan, 2011; L€ahteenoja \& Pirttil€a-Backman, 2005; O'Connor, 2008), and adopt interpretive stances on students' testimonies of being recipients of caring teaching (Larson, 2006; Ravizza \& Stratton, 2007), almost all have been carried out in compulsory, school-age contexts, rather than in higher or university educational settings. Furthermore, there are very few studies that seek to comprehend 'caring teaching' more completely and particularly from a perspective of constructing theory about caring teachers themselves (Walker-Gleaves, 2010; Velasquez, West, Graham, \& Osguthorpe, 2013). This research seeks to contribute to the scholarship in this area, and theorize the caring teacher within higher education.

\section{Literature review}

In pedagogic terms, practitioners, teachers and tutors alike are obliged to care (Noddings, 2003; Thayer-Bacon \& Bacon, 1996; Wilcox, Winn, \& Fyvie-Gauld, 2005). The concept of caring as the basis of a mindful teacherestudent relationship is enshrined in the professional standards of education systems worldwide, and evident in the foregoing descriptions of professional practice is care in its diversely relational forms, as human concern, moral responsibility, individual attentiveness and personal responsiveness.

Primary and secondary schooling teachers in the UK for example have both common law and statutory duties of care explicit within the Secretary of State's guidelines and the UK Teachers' Standards and they must, 'build relationships rooted in mutual respect' (DfE, 2013, p.14). In the USA, the California Standards for the Teaching Profession exemplify Standard 1 e 'Engaging and Supporting All Students in Learning', by requiring the use of knowledge of students to engage them in learning, and specifically asks teachers to 'build trust with students and foster relationships so that students 
can thrive academically' (CSTP, 2009, p.5). Similarly, the New Zealand Practicing Teacher Criteria have as their first key indicator of fully certificated teachers' practice 'To engage in ethical, respectful, positive and collaborative professional relationships with learners' (New Zealand Education Council, 2015). Furthermore, in the Task Force for Teaching Excellence Report to the Minister of Education in the Government of Alberta, Canada (2014), participants in the consultations said that excellent teachers are:

Compassionate, empathetic, caring, kind, understanding, and relationship builders. For example, a student participating in Task Force consultations said: "Truly having a good teacher is to be able to connect with him or her and their teaching method. More than just the way he or she teaches, but on a personal level as well. To be able to connect with someone will truly make it easier to understand what they are saying and to comprehend material in depth". (p.19)

However, the place of relationships, especially caring ones, internationally within higher education is far less clear and their discourse within the sphere of professional obligation is markedly different. For example, under the UK Professional Standards Framework for Higher Education, academics must 'develop effective learning environments and approaches to student support and guidance' and 'respect individual learners and diverse learning communities' (HEA, 2013, p.3). In the context of the USA, the Council for the Advancement of Standards in Higher Education Studies (2006) only requires higher education teachers to create educational environments that are 'safe and secure' and to be 'trustworthy and maintain confidentiality' within the arena of teaching effectively but there is no overt and explicit mention of constructing attachments or of building bonds or the reasons for doing so, as with other professional frameworks.

Although there are very few studies in the area of teacherestudent relationships in general in higher education, and within these, even fewer on caring relationships, such studies as they exist have repeatedly suggested that creating purposeful relationships within higher education is critical to student learning (Bergin \& Bergin, 2009; Deakin Crick, McCombs, \& Haddon, 2007; Hagenauer \& Volet, 2014a). Furthermore, research appears to suggest that caring relationships in particular are of great salience to students, who appear in such studies to be convinced of their educational impact and thus that teachers in higher education should by extension, be 'caring' (Walker, Gleaves, \& Grey, 2006; Docan-Morgan, 2011; Hixenbaugh \& Thomas, 2006). Qualitative studies analyzing the nature of caring teaching in practice (Walker et al., 2006; Dallavis, 2014; Edwards \& D'Arcy, 2004; Goldstein, 1999; Larson \& Silverman, 2005; Velasquez et al., 2013) establish the extensive relational nature of pedagogic care, suggesting that caring teachers have particular 'exemplifiers' in their practices 
including the ability to: listen to students, show empathy, support students, actively support students' learning, give students appropriate and meaningful praise, have high expectations of work and behavior, and finally, show an active concern in students' personal lives. However, the research that exists in this field does not expose which of these exemplifiers are more significant in the construction of the 'caring' teacher. This study, by seeking the teachers' perspectives on pedagogic care, and allowing possible muddiness between motivations and practices to emerge, offers a rich account of what these exemplifiers mean in a higher education contact, and as such, given the complexity of delineating the 'good' and 'caring' teacher, is an important contribution to the literature.

We can assert that pedagogic care manifests itself at several different levels simultaneously, with individual 'caring' teachers constructing a complex web of intentions and actions (Goldstein \& Lake, 2003). But what emerges from the literature is the variation in the degree to which such teachers create the conditions, or in some cases, take responsibility for, students' eventual achievements. Related to this, there is evidence to suggest that 'caring' teachers define learning outcomes more diversely and in make fewer distinctions between cognition and emotion as they impact upon learning. Such a vision of teaching is articulated by Rendon (2009) as 'sentipensante pedagogy' that involves the ability to see the connections between seeming opposites, such as thinking and feeling. Within these studies, it appears that caring teachers appear to be motivated to do all that is possible to maximize a student's chance of success and the literature attests to the means by which individual teachers carefully articulate and precisely fashion their caring philosophies and practices (Larson, 2006; Noddings, 1986; O'Connor, 2008; Weston \& McAlpine, 1998; Zembylas, Bozalek, \& Shefer, 2014).

However, there are limitations within the current research, and these lead to an imperfect understanding of the nature of pedagogic care, the distinctions between care in practice and the rationales and motivations of teachers who care, particularly in higher education. First, teacher care studies to date have tended to focus on particular groups of recipients of caring, emphasizing the cultural responsiveness element of pedagogic care actions. As such, the field is replete with studies of teachers whose care has empowered and liberated particular students through pedagogies of critical emancipation (Barber, 2002; Lippke, 2012; Monzo \& Rueda, 2001; Robson \& Bailey, 2009; Wilcox et al., 2005). Yet such studies have rarely occupied themselves with the possibility of transfer of findings to other students, nor of explicating the precise nature of emancipatory care and how it may differ from care as an antecedent of understanding students' learning progress more generally. 
There is also scarce empirical research identifying the broader contextual dimensions of being a caring teacher in relation to the diverse institutional settings in which teaching and academic work occurs in higher education, since the majority of scholarship is located in studies on school teachers' caring. Research that examines the tensions between particular types of activity, particularly when seen through the lens of the gendered nature of much teaching and academic work (Walker et al., 2006; Harley, 2003; Hauver James, 2012; Mariskind, 2014; Zembylas et al., 2014) would be particularly significant, especially given claims about the feminization of higher education in the UK (Morley \& Lugg, 2009), and in particular the tensions between the pedagogic structures that purport to support and nurture diverse student bodies more responsively in the service of key National Student Survey metrics, but in doing so, supposedly reduce valuable research time and thus potentially impact on national Research Excellence Frameworks and ultimately the status of the university (Leathwood \& Read, 2009).

Another issue that stands behind the motivation for this study concerns the nature of the literature on pedagogic care and what this communicates about the meaning and status of care as a mechanism to effect change, not just in pedagogic, but also social terms within education more generally. Whilst caring has for a very long time been associated with a form of character education for particular forms of society (Nowak-Fabrykowski, 2012), research is increasingly concerned with the impact of teacher care on student outcomes (Ferreira \& Bosworth, 2001; Larson, 2006; Wentzel, 1997 ) and particularly pro-social related ones (Jennings \& Greenberg, 2009). The reasons are in many cases instrumental, and both impact upon school and district measures of institutional performance, and affect pupils themselves. For example, students are increasingly under pressure from forms of social activity that place them at risk, such as cyberbullying, gang membership and drug use (McCuaig, 2012; Muller, 2001). At the same time, students are pressurized to perform more resiliently, and within higher education, to more robust academic standards and with better progression outcomes of all kinds (Dallavis, 2014; Fitzmaurice, 2008; Rivera-McCutchen, 2012). In the context of higher education, such issues emerge as a battle for the soul of the student, with learning outcomes such as resilience, persistence and prevalence for example, frequently regarded as adjunct to the business of learning, and thus as 'soft' and optional but outcomes such as knowledge gained, or grades achieved, as 'hard' and thus more worthy (Zepke \& Leach, 2010). By extension, teacher behaviors that privilege the latter exert a greater power in research terms, since they hold the promise of linking particular pedagogic practices to such coveted outcomes.

This research has as its purpose the development of a theoretical model of the caring higher education teacher from the teachers' 
perspectives themselves. It also seeks to identify and explore factors that affect the nature and practice of pedagogic care within higher education. A process of reputational case selectionwas used to identify caring higher education teachers and these were then interviewed multiple times in order to identify the individual encompassment of caring teaching, from motivation, through intention, to action and consequence. It is important to point out that the study aim was not to investigate the definition of pedagogic care as such, and nor was it the intention of the study to evaluate the impact of care on student learning outcomes, but to illuminate the issues that a teacher classified as 'caring' would perceive to be significant in espousing and practicing pedagogic caring. This paper will explore the methodological process that was followed and as a result, will then present the emergent theoretical framework. Illustrative data will be presented alongside the representation.

\section{Research design}

\subsection{Methodological approach}

This study adopted an inductive interpretive approach, utilizing a qualitative design in order to establish how teachers in higher education perceive pedagogic care and as such, establish a caring environment in their teaching and learning e in other words, how they become and exist as 'caring teachers'. Within this study, it was essential that teachers' beliefs and intentions emerged through as naturalistic process as possible, minimizing the impact of prior assumptions and expectations. Experiences of care and caring as recounted by teachers and students alike give rise to palpable tensions between emotions, hopes and fears and the personal, political, economic and social contexts of education. Building upon these considerations, the research design chosen for this study is an interpretive analytical one, where the researchers attempt to understand and explain the participants' experiences, whilst acknowledging the 'entanglement' (DeMarrais \& Tisdale, 2002) of the participants within the subject themselves. In analytical terms, the study employed the Grounded Theoretical approach (Glaser, 1978; Glaser \& Strauss, 1967; Strauss \& Corbin, 1990, 1998) in order that theory could be constructed inductively from the systematic interpretation of the data. Ethical approval to conduct the study was provided by the researchers' home university as well as the university under study. It was sought at the latter university to ensure absolute transparency of research processes given the possibly reputational impact that the studies' findings could have upon the academics within the study.

\subsection{Selection of the participants}

Selecting the participants is a particularly significant element of the process of grounded theory research since it represents the core conceptual structures that stand behind the ultimate development of the theoretical model. Consequently, the nature of the process of 
sampling, 'theoretical sampling', is very particular and carries with it, specific structural meaning. In essence, sampling in grounded theory proceeds on the basis of adherence of the participants to theory, rather than as individuals with associated subjectivities (Strauss and Corbin, 1990). However, due to the context of this research, a complex procedure for selection and sampling was designed that balanced the methodological rigor of grounded theory, with the conceptual complexity of care pedagogy. This process will now be outlined.

For this study, participants were selected using Reputational Case Selection. A sample of six purposeful 'cases' was selected within a Faculty of Social Sciences at a large university in the North of England, UK. All the participants were nominated by knowledgeable professionals in their field, a process known as 'Reputational Case Selection' (LeCompte \& Preissle, 1993). Caring is a complex phenomenon to investigate using the beliefs and experiences of academics themselves yet utilizing student feedback in assessing such a subjective quality as a means to identifying academics in the first place is also unreliable. 'Reputational Case Selection' seeks to militate against these difficulties by harnessing 'expert' and 'professional' judgments on subjectivities, where possibilities of bias and favoritism are minimized. As a result of the selection, literature is then used to 'ground' the claims for inclusion in the study.

In the case of this study, the experts and professionals were defined as Faculty Colleagues and members of the University Promotions and Conferment Committee; in all cases the staff providing judgment were familiar with academics' work. A letter was sent to the experts concerned, briefly discussing the purpose of the study and asking each to recommend a caring faculty academic and indicate the reasons they considered the academic to be caring. Seventy-two responses out of a possible ninety-seven were obtained, thus representing $74.2 \%$ of the total respondents. These responses generated the nomination of fifteen individuals along with recommendations for each in the form of short paragraphs. Each of the recommendations was then scrutinized in terms of the level of agreement of their written testimonials with the literature on caring teachers and academics, specifically the pedagogical behavioral 'caring exemplifiers' of:

- Listening to students

- Showing empathy

- Supporting students

- Actively fostering learning in class

- Giving appropriate and encouraging feedback and praise

- Having high expectations in standards of work and behavior

- Showing an active concern in students' personal lives

These were essential in serving the purposes of the research, 
since they formed the theoretical criteria necessary to establish the sample for the study, thereby 'grounding' the research, albeit acknowledging their conceptual difficulties as outlined earlier. Secondly, the use of student-generated judgments within the literature ultimately contributed to the validity of the 'cases' selected, since it provided checks and balances to any skewing of recommendations due a particularly unusual or subject-specific interpretation of care and caring.

The participant recommendations were then analyzed with respect to whether their nominations matched all of these and the process generated seven participants. These were then contacted about participating in the research as 'caring academics'. Out of these, one declined to be part of the research and six subsequently became part of the project and stayed throughout the whole period of the study.

\subsection{The interview process}

Rossman and Rallis (2003) assert that the interview is 'the hallmark of qualitative research' (p. 180). Interviewing is a method through which one gains understanding of the participant's world through experiencing their speech and response. Within this research study, the research purposes encompass past beliefs and experiences and present identities and practices. In addition, the research seeks to elicit the perceptions of a particular concept, pedagogic care. As such, the interviews required a systematic structure that was thorough but allowed for probing and provocative questions. The study adopted a four-interview schedule that utilized two interview 'frames' that complemented and overlapped. One aligned strongly with the interpretive nature of the inquiry and served the purpose of understanding and explaining the research participants' experiences from the 'inside' (Charmaz, 1995), by illuminating the meaning that higher education teachers assigned to the concept of caring. The other frame was predicated upon a storied identity utilizing Seidman's (1998) three-stage model and which afforded the participants and the researchers appropriate space in which to build theory inductively and insightfully. Specifically, each interview drew upon a life stage in each participant's development, and used this as a basis to explore elements of pedagogic care from the teachers' perspectives. As an example, the first interview was subtitled 'On being perceived as a caring teacher in higher education', and sample questions included:

- What factors do you think were commonly used in identifying

- you as a caring teacher? (Common factors will be shared with

- the participant). Do you recognize yourself in them? How?

- Do you personally consider caring to be an intrinsic part of your

- teaching or academic work? How?

- What differences, if there are any, could you identify in yourself,

- according to your experience, between when you knowingly

- care about your students, and when you're not conscious of it? 
The second interview concerned the theme 'Being a caring teacher', and example questions included 'If I went into a typical class of yours, what might I expect to see you doing?' and 'What does the way that you organize your classes say about your beliefs?'. The third interview was focused on 'Becoming a caring teacher' and sample questions included How did you become a university teacher?' and 'Why did you choose university teaching over other sorts?'. Importantly however, a fourth interview was carried out at the end of the study, what Seidman (1998) refers to as a 'reflection on meaning' (p. 12) interview. In this interview, participants were asked to reflect on their perceptions of themselves in terms of the conceptual basis of care in their work. In all, twentyfour interviews, four with each of the participants, were conducted over a period of fourteen months. Interview durations were variable, but most lasted no more than $70 \mathrm{~min}$, with occasional ones lasting $90 \mathrm{~min}$. During the interviews and meetings, digital recorders were used to record speech, and these recordings were transcribed as quickly as possible afterwards. Transcriptions were offered to each participant after their interviews to confirm or clarify data, and support an additional element of the study's validity.

\subsection{The participants}

The subjects for the research were varied in the experiences, their ages, their disciplines and their positions within the university. Each participant was invited to choose a pseudonym based upon some aspect of their teacher identity that they wished to encapsulate. Their demographic details are shown in Table 1.

\begin{tabular}{|c|c|c|c|c|}
\hline Name (pseudonym) & Age & job titile & Discipline & Number of yeas of teaching expentence \\
\hline Exhann & 53 & Senior lecturer & Ed ucatonal comput ing & 19 \\
\hline Fenella & 29 & Texching fellow & English & 6 \\
\hline Charity & 44 & Prodessor & Phyelcs education & 20 \\
\hline Mirelle & 59 & Senior lecturer & Modern foreign languages & 26 \\
\hline jud & 38 & Texching fellow & Sochal work & 13 \\
\hline Scarlet & 39 & Lexturer & Crim inology & 7 \\
\hline
\end{tabular}

\subsection{Coding processes and outcomes}

The interviews in this study were transcribed and analysed according to the constant comparison method (Strauss \& Corbin, 1990). This adopted the sequence of Open Coding, Axial Coding and Selective Coding, with the overall aim of being 'theoretically sensitive' (Glaser, 1978).

In the open coding procedure, data were examined closely and carefully by both researchers, with the aim of identifying with as much reliability as possible, participants' thoughts, feelings, motivations and values, in relation to the particular themes mentioned in the interviews. The emergent codes were as faithful as possible to words and phrases used in the interviews, and resembled as closely as possible the original intentions and contexts. This was a critical stage in construction of semantic sensitivity within the 
transcripts and codes. The emergent codes (there were 372) were then compared to establish their descriptive content and to confirm that they were faithfully grounded in the data. The next stage, axial coding, consisted of the structuring of the codes into categories.

Constant comparison formed the basis of this stage, where categories were compared with each other, and in addition, between codes, interview themes, and interview responses, especially in connection with the underpinning relationships between codes. Broadly, these referred to whether the sub-categories were causal (specifying actions or incidents that led to the phenomenon under study); contextual (specifying the characteristics that describe the phenomenon); and finally, intervening, or the issues and structures that facilitate or impede the phenomenon. The final stage of the process, concerned the use of selective coding, whereby categories were clarified and then structured according to a form of narrative to give a holistic meaning to the data, and which therefore culminated in the construction of a theory of pedagogic caring in higher education.

\section{Findings}

The categories emerging out of the analytical process in this study comprised: a relationship at the centre; compelled to care; caring as resistance; and caring as less than. For each category we now present a discussion of the sub-categories with exemplifying quotes. A schematic of the main categorical structure in the research is shown in Table 2.

\begin{tabular}{|c|c|c|c|}
\hline Categary & Causal sub-category & Contextual sub-category & Intervening sub-category \\
\hline $\begin{array}{l}\text { A relationdhip at the } \\
\text { entre }\end{array}$ & $\begin{array}{l}\text { Belies about learning } \\
\text { Belies about the nature of teaching } \\
\text { Primacy of theories } \\
\text { Impact of teacher's own training. }\end{array}$ & $\begin{array}{l}\text { Knowing all students' numes quidkly } \\
\text { Responding rapidly to queries } \\
\text { Sending solicitous emails in the context of } \\
\text { students difficulties } \\
\text { Having well devebped strateges and policies at } \\
\text { individial kvel }\end{array}$ & $\begin{array}{l}\text { Institutional responsive policies } \\
\text { Personal feelings of fail ure } \\
\text { Muddying boundaries }\end{array}$ \\
\hline Compelled to care & $\begin{array}{l}\text { Explicit belief system } \\
\text { Personal actian-tela ted evidence } \\
\text { Explicit pedagogic values }\end{array}$ & $\begin{array}{l}\text { Working to support students at all hours and } \\
\text { times } \\
\text { Finding ways to baditate student learning } \\
\text { Being explicit in all aspects of student equality } \\
\text { and diversity }\end{array}$ & $\begin{array}{l}\text { Love of teaching } \\
\text { Exhaustion } \\
\text { Confission over roles } \\
\text { Occupational freedom } \\
\text { Fear and lack of security in other occapational are as such } \\
\text { as resear d. }\end{array}$ \\
\hline Caring as tesistance & $\begin{array}{l}\text { Need for autonomy } \\
\text { Par adigmatic dissonance (teaching- } \\
\text { research nexis) } \\
\text { Spiritual/ethical dissonance }\end{array}$ & $\begin{array}{l}\text { Questioning academic processes } \\
\text { Defending students in boards of studies } \\
\text { Stbventing processes to assist the students }\end{array}$ & $\begin{array}{l}\text { Sympathetic olleagues } \\
\text { Disciplinary sapport } \\
\text { Contractual issues } \\
\text { Personal familial support } \\
\text { Mental fortitude }\end{array}$ \\
\hline Caring as less than & $\begin{array}{l}\text { Institutional policies } \\
\text { Personal experience of academia } \\
\text { Discursive construction of the } \\
\text { academic } \\
\text { Emotive work is women's work }\end{array}$ & $\begin{array}{l}\text { Time dedicated to student support in timeta ble } \\
\text { Researching over teaching } \\
\text { Defending promotions/awar ds } \\
\text { Moving to a different institution } \\
\text { Countering explicit discourse of colleagues } \\
\text { Doing action research }\end{array}$ & $\begin{array}{l}\text { Student retention } \\
\text { Student persistence } \\
\text { Students acknowhigement } \\
\text { When students involve you in the ir lives, weddings, } \\
\text { christenings, funerals } \\
\text { Research/time conflict } \\
\text { Publishing top rated research } \\
\text { Promotions } \\
\text { Awards } \\
\text { Working at an elite university } \\
\text { External metrics }\end{array}$ \\
\hline
\end{tabular}

\subsection{A relationship at the centre}

'A relationship at the centre' was a powerful category in the teachers' responses. In this study, the participants showed the most explicit attention to relational matters and reflected critically on every nuance of their behavior if it could feasibly affect their students, 
their pedagogies being centered almost solely on understanding the act of teaching as a principal causal means of making learning happen at a deep and sustained level. One code illustrates the fact that relational teaching for these teachers rests on specific pedagogic theories allied to trust, openness and reciprocity that create environments for academic discomfort and critical thought. Mirelle described her ideas on this:

If they can't trust me, then they can't trust me to give them help to learn, to grow.

Other codes exposed the notion that each academic's teaching environment was shaped toward fostering harmony that would ultimately serve the purposes of establishing the most conducive and intimate relationship to further the ends of their pedagogy as deeply entrenched theoretical orientations. Mirelle went on to say how this was achieved:

Reflexivity is what I do, I pu tmyself out there, I send messages to provoke a response, ask how my students are coping, feeling, but I am painfully aware of its consequences, I'm making those particular consequences happen, because doing that, having those bonds, is the nuts and bolts of learning how to be critical and discriminate.

Looked at in this way, all the participants created their environments as forms of what might be termed 'macro' level responsibility in the way that they had great knowledge about their students' contexts. Charity reiterated this many times:

I try to know the ins and the outs of the students. In one case, one had cancer mid way and I visited her in hospital and wrote letters, long letters discussing her work.

The participants presented testimony that they were engaged in teaching as a sociocultural activity, one where as a result of various forms of engrossment, negotiated through their relationships, all sought to create in their students not simply forms of knowledge or development of skills, but forms of different 'being': these were evident in the sub-categories of extensive beliefs about teaching and learning and the nature and purpose of both. Charity exemplifies this as:

Every bit of that class I remember so richly, it was one of those classes where you can't imagine how your relationship could have been any better or how you could get to know them any more. Sometimes I remember feeling sick during class, it was as if it were a drug Iwas on; the students seemed to respond to and fill every fragment of caring that I 'did' and ultimately began to change themselves. 
Intervening codes exemplified the personal barriers to maintaining caring philosophies when personal feelings conspired against them. Participants unpicked facets of pedagogic relationships and counseling-type interactions and emphasized that blurring boundaries was a relational pedagogical hazard. As Fenella suggested:

We're so used, as academics, to having as a default, a view of learning and teaching that encompasses cognition and little else, that anything else at all, seems a radical departure, a sort of the boundaries.

It was clearly critical to all of them that they were involved in actively making the students 'different' and consequently, failure to do so was an important code, whether through students failing to persist or succeed despite the investing of emotional labor, or whether through personal shame that a student fails to thrive academically despite adherence to pedagogic ideals. Policies could be harnessed to reassure participants that although student support for example was institutionally important, it may not always provide desired outcomes in terms of student achievement. Institutional Codes within the 'relationship' category thus recognized tensions between the needs of the academy as against the imperatives of contemporary student-hood.

\subsection{Compelled to care}

A compulsion to care was a category of great and explicit salience for the participants in this research but codes illustrated the complexity and frequent contradiction of the teachers' intentions and motivations. Charity was strongly aware of this:

I suppose that I take a very interrupting view of teaching in that it's there to make students different. And that's not coming from the perspective of especially student-centred principles. Not really. Scaffolding, but not as passive assisting to learn, God no (laughs). Aggressive scaffolding if you like, so that I find away to facilitate whatever counts as learning.

One group of responses concerned professed intended pedagogic views of caring teaching that reflected individuals' naturally affective tendencies and preferences. Such ideas were often developed through participants' own training but shaped and sharpened through the lens of institutional discourse, forcing purely cognitive developmental matter, yet at the same time, to somehow be aware of the emotional impact of learning, especially in relation to student retention. As Eachann put it: The whole concept of caring to me is the complete rejection of the dualist sort of thinking that says 'you can give students knowledge when they're sad, happy, nice to them, horrible to them, because it's the knowledge that counts'. It just doesn't work like that. I think that it's an absolute critical bit of learning 
that students see that emotion and being a human and learning, to be the ultimate intellectual and scholar I suppose, is all mixed together, it can be absolutely desperate but it's absolutely necessary.

He went on to say that:

I think, though I can't prove it of course, that what I do makes a huge difference to whether students prevail ... I make it impossible for students to even want to leave ... not impossible to leave, but to not want to leave ... That kind of governs what I do ... it can't be otherwise ... what would be the point? They wouldn't be achieving anything if they weren't here anyway, so they kind of have to be here to be affected, it doesn't matter how. The code of evidence in relation to how personal teaching experience impacted upon the perceptions of participants was significant: all the teachers however experienced or novice, appeared to be vigilant as to responding to students' needs modifying them toward student centredness over time, suggesting a tendency to mediate experience through a very specific lens. Such a journey was described by Jud:

When I first went a course about teaching in higher education, there was a lot of focus on student diversity and being student centred, but the more you do it...teach...the more you realize it comes to you, that actually that's all about control and coercion. Real student centeredness is in listening, hearing what you don'twant to hear as well as what you do. You find away. I think you can't not (emphasizes word) find a way.

The codes demonstrate that ideals and visions of teaching are resilient, despite collisions of images and beliefs from participants' own personal view of what teaching should be, and the complex social and cultural stage that they find in the classroom. Charity found this difficult to talk about, and as she said:

Oh, I don't know why I was chosen, just tell me a few...no show me the whole lot...no, I don't really want to know. What sort of general thrust is there? Is there a concentration on kind of the academic stuff, so that I don't come over as an 'earth mother' (laughs) - that's what I've been called. I feel as if you're not supposed to be caring or at least admit to it as intent. I think that it's being kind, warm, expects a lot, demands a lot, can be cruel. Codes in the causal and intervening sub-categories converge in relation to the major category of 'compelled to care'. The participants brought with them myriad personal histories that included beliefs about the activities and processes of teaching within higher education, the attributes and knowledge demands of academics, and the expected attitudes and behaviors of teachers working within the higher education context. These expectations frequently caused confusion of roles however, and created insecurity particularly when incidents relating to their care had seemed to expose the academics, in which case they resorted to different types of behavior and activity to somehow 'normalise' 
their caring.

The codes in the contextual category revealed that all of the participants in this study had lives that criss-crossed with elements of social justice issues, and considered that their activities outside formal academic structures were as important as their academic work and all sought actively to be involved in the lives of students and the university and its wider community. All of the participants presented a clear image of themselves at the outset, and there was great clarity in the expression of the various factors that served to both undermine and rigidly defend their compulsion to care, all codes being expressed in forcefully descriptive language: a love of teaching, freedom to be yourself, exhaustion with their role, confusion over their role, and fear about not performing. As exemplified by Fenella, such overwhelming compulsion is all enveloping and almost spiritual in its experiencing: I adore that my work is just about a total immersion and I make no apology for the rigour and the shoutiness that I expect of my students. Ha! Sometimes I can't think straight between feeling elated when we've hit on something together, or when I realize something as I'm teaching, but other times, I feel confused over what I'm here to do e to give of myself, like, to serve, or to be, and in being, to provoke. It's frightening and confusing.

\subsection{Caring as resistance}

The responses of the participants that refer to the category of 'Caring as resistance' concern the variation in the conceptualization of dissonance in the institutional-personal nexus. One group of codes concerning the institutional element of this relationship dealt with the intrinsic complexity in the purpose of a 21st century university, encapsulated in whether it was to have a moral purpose, or to be economically sustainable. A related theme concerned the crystallization of this philosophical collision in individual terms, participants indicating that in their everyday relations with students they wished to distance themselves from the economic motive and construct themselves as autonomously caring, rather than customer caring. But this had a downside, and frequently gendered meanings of caring were marshaled to explain particular academics' behavior, as Charity explains:

There have been many times when I've sat as a senior member of staff, on academic boards and mitigation committees, and it's seemed to be that academics make the flimsiest of judgments about people's lives imaginable, with scant knowledge about how that will affect their future progress. People have said after the boards 'you're like a mother to those students'.

A policy dissonance code was very evident in this category too: the resistance to the grander narrative of philosophical purpose was translated into an everyday moral resistance to the operationalization of policies that participants found to be allied to good business decisions rather than learning. Eachann exemplified this through their experience of student support panels: 
For me, it all hinges on being moral as part of a wider set of ethical principles that are only circumscribed by the clear mission of academic excellence, since the stated purpose of academic life is surely to study and achieve. But it is unethical not to cause learning actually. Yes it is ...immoral to be cruel by omission of something, I don't know, not replying to emails, not returning work on time, etc etc. but unethical not to try and cause learning through whatever means possible.

Standing behind the manifestation of these value-related codes was another set of codes allied to the personal aspect of the nexus, and this emerged as a code set on a continuum of purpose, from spiritual or ethical dissonance, where individuals felt that their core beliefs were in conflict with what they perceived the institution was asking themto do, to at the extreme, outright alienation, where the participants existed in a marginalized parallel sphere and inwardly and outwardly resisted policies and practices that created a sense of existential crisis.

Although manifesting itself in nuanced ways depending upon experience of the teacher, there was clear consistency in the pedagogical purpose of caring in this study.

'Caring as resistance' also exposed the themes of 'defence' and 'subversion'. The significance of defence is clearly a mechanism in which caring individuals positioned themselves as buttresses against what was perceived as the steady infiltration of interpersonal values with operationalized processes from externally imposed values. Eachann articulates this well, making clear the necessity for maintaining a steely inner core of defence:

... it's about having that deep relationship with students but buffeting them and you with some kind of defence that is defiant in the face of any latest trend but that also affords you some kind of rationale to be a reflective practitioner. This is especially so in recent years because when things like the National Student Survey come round there's palpable tension that many academics are just visibly 'caring' because of the need to get high ratings and then it assumes gradually less importance till the next time.

A 'subversion' code illustrates this cogently, participants perceiving themselves to be important instruments in maintaining what they imagine to be the core values of higher education that cannot be open to diminution, as illustrated by Fenella and Jud: It's clear to me that there's a kind of two lane highway thing going on, where students are subject to one form of relationship which clearly isn't what they believe they've come here to experience. (Fenella)

I think that that accords well with the notional institutional thing about pastoral support...you know...caring for students ... so that they don't leave ... I feel that it's my duty to subvert that commercial or whatever purpose, and expose something deeper, something that listens to them as people. (Jud) Other codes appear to suggest that the participants value relational resources in their construction of the dissonance and 
disruption that appears to constitute their 'caring as resistance', as illustrated further by Jud:

I am their go-between, the university sees itself as customercare focused, whereas I see it as heart and soul focused. Real learning, meaningful learning focused, the messiness, rubbishness of it all, rather than learning contracts and schedules.

The issues that impede their caring were perceived to be individual: participants' mental states, their resilience and their ability to persist and prevail in morally complex climates. Alongside, contractual issues were impediments to caring: participants mentioned the prerequisite of researching and visible scholarly outputs, which were significant contractual obligations, yet jeopardized their physical and mental capacity to do these and yet care without limits. Mirelle articulated this thoughtfully: You have to be really careful who you trust, and speak to about what you think. Really strong, you must be really strong, to know resolutely that what you're doing is actually about what underpins... what should be beneath studying in a university... autonomy ... the autonomy to say hang on, this is what I'm doing, this is why I'm doing it. But you have to be so strong. So strong.

Perhaps unsurprisingly, the issues that acted to facilitate 'caring as a resistance' were predicated upon relational resources, in particular family members who understood emotional turmoil, sympathetic colleagues in and outside disciplines who supported paradigmatic differences in pedagogical purpose. Eachann had an experience of student feedback that exerted a toll on his emotional resources and brought into focus his rationale to resist using care: I have to really examinemyself as a result of this and see if there is something wrong. What is the basis of my caring about students if, they don't care, if they reject my values, then what am I caring about? This place is not a religious experience, I can't expect all students to respond as I'd want them to.

\subsection{Caring as less than}

This category suggests that feelings of conflict within academics can systematically begin to undermine personal ethics, particularly if these are consistent with overarching philosophical frames of thought. The codes in the causal category were indicative of teachers who felt simultaneously the need to entrench their public faces through repeated perceived attacks on their pedagogic actions and motivations, but at the same time, to re-construct their private faces through a series of actions and achievements related to their roles, which acted as lenses through which to view pedagogic Oh the things that people have said are very lovely. I'm shocked. But it means more and means less at the same time that it's staff. For example, several of them make comments about my homeliness drawing students out of their shells. Call me paranoid, but what does that mean? It sounds like it's something like 
baking cakes or taking them home with me or something, not very, very un-academic (big sigh).

For example, there was an expectation of the caring role in the teaching fellows, despite support or allied terms being in any contract or role description. Jud suggested that:

Well it's a funny old formula ... like the teaching is dirty work, you know, that you have to come into contact with the students (laughs). I'm doing some action research at the moment, relationships online, that everyone is desperate to see the results of, but l've been told it won't get much credence higher up because it's limited. I'm not sure whether it's the topic, the methodology or because I'm me and I do this sort of thing. Conversely, the Professor in this study felt that there was an expectation of caring "in the realm of the Oxford tutorial model" whereby the intimacy of the tutorestudent relationship was judged as absolutely necessary but only in order to elicit higher levels of academic performance in exceptional students. All the teachers in this study expressed the notion that caring was somehow 'less than': it was quoted as being a pedagogy of difference and of inclusion by some, and therefore only useful to those students who were in difficulty, and would therefore only respond through the use of certain pedagogic actions, as Mirelle explains: Yes, it's the same old thing, it's that you don't have to have a reason for high academic standards, but that you do have to have a reason for high relational and pastoral standards. I'm sick and tired of people saying, well, you're wasting your time with so and so, they don't need you to look after them. Of course they do! Should we have a list of who is worthy and who is not? And anyway, it's a ridiculous distinction, high person-ish standards ARE high academic standards.

But equally, the teachers in this study perceived that caring was viewed as time consuming and wasteful for a large group of students who had no particular academic difficulties, as if the majority of students would not benefit from the relational intensity or motivational displacement described in the literature on caring teaching. As Eachann put it:

If you regularly talk with colleagues about for example helping when students have a financial need, or simpler things like asking students if they're ok if they look sad, people imagine that there is some kind of spurious reason for your actions ... keeping quiet is so much better because people can't level at you the sort of 'well he's doing that because he wants to be different to the rest of us and show he's an instrument of management' or at the other extreme, 'he's cosying up to students'.

The intervening and contextual codes demonstrate the perpetual difficulty of trying to balance achievement and output in distinctly different, parallel worlds, or as Eachann stated: I feel I've backed myself into a corner with this way that I am 
now. I feel that I've lost touch with why I'm here in the first place and apparently seem to be spinning off into a disciplinary vacuum and only being judged on what I feel rather than what I know. Or rather I know what I am but I'm finding increasingly that I have to find a justification for it that convinces people at all levels. I'm not sure I like who I have become any longer. It's rather painful to think about it all.

The emergent codes reveal that all felt passionate about their roles as teachers (no matter how varied these were) and were validated through explicit involvement in students' lives, often long after the students had ceased to study with them, but all sought to justify their position as academics who cared, through the use of particular forms of action that they themselves did not necessarily subscribe to, including particular types of research, making themselves available for award nominations, writing nominations themselves. Jud for exampled, felt as if he was always countering his past at a much smaller community-based university: I'm a bit sick of people saying 'well he's from $\mathrm{x}$ institution where they are more teaching-led, so it's not surprising he behaves like that'. I know that people do. What I would really like is to go to somewhere really small, really elite, or just win a huge grant here.

One of the academics engaged in specific action research projects to provide an evidence base for his particular espoused pedagogies:

This enables me to have a kind of evidence base so that I can say about caring for example 'well it's not that this is just a selfindulgent whim, this is founded on well thought out pedagogic practices'. But you clearly wouldn't think that to look at the comments e they seem to imagine that it's a function of me as a caring person alone.

Of particular note were the codes related to external validations of caring such as promotions, and successful occupational moves to high-ranking, high status universities, which simultaneously gave participants credibility whilst removing them from their principled pedagogic arena. However, the codes for caring as less than revealed a gender bias that had hitherto been absent from the analysis: the participants stated that men may just as actively seek caring student attachments as purposeful strategies yet their reasons for doing so must be cloaked as high professional standards, whilst those for women were to be expected, as one participant put it "emotive work is women's work". The code relating to the discursive construction of the higher education academic revealed a profound dilemma about the nature of the academic as a type of personality: whilst to be disposed as an idiosyncratic scholar was acceptable, the 'caring teacher' image was not, and threatened all that the participants had so clearly cultivated in their efforts to be 
both scholarly and caring. Charity put this most forcefully: I have been doing a lot of thinking over this last year and I think that I have perhaps emphasized parts of me as an academic that are not so commendable as I imagined them to be. I work to a very high standard, rigorous academic standard, and I need you to knowthat this in noway conflicts with or detracts from, other things I have told you about what I do.

And echoed Fenella, who noted that:

At the moment I feel confused about this. I am tentatively gratified that people ... colleagues have acknowledged me, but concerned that I'm not sure whether I've now fitted in and if so

It is perhaps extremely significant that the codes for the intervening sub-category are so great in number within this research: the participants were unequivocal that caring presented a frequently poignant and troubling ideology that somehow needed many exemplifications of how it could be worthwhile, or what might serve as refutations of the notion that it was worth less. Participants for example, invoked the idea of 'false consciousness' as an institutional response to caring teachers, and stated their hope that as an institutional policy, someone would see its importance and impact.

5. Discussion

5.1. The conceptual narrative and an emergent theory The phenomenon under inquiry in this study has been the teachers' perspectives of pedagogic caring in order to facilitate the construction of an integrative model of the caring teacher within higher education. Importantly, rather than presenting a definitive paradigm of a caring higher education teacher, the integrative model that we construct articulates a complex web of principles, thoughts and practices that may be used by other researchers to investigate both its transferability and its generalisabilty. The inductive interpretive paradigm that we adopted, and within this, the application of grounded theory processes and techniques, enabled us to move beyond simply exposing teachers' thoughts about caring within higher education, to insightfully and critically discerning how their practices and principles entwined to form coherent pictures of the caring teacher in higher education. Instead of concentrating on particular practices and asking the teachers concerned to account for these, we examined the teachers' thoughts on others' assessments of them, and through our staged interviews, privileged the reflections of the teachers over time, not asking the teachers to 'straighten out' meanings and experiences. Utilizing this methodology and these techniques exposed both strengths and weaknesses however.

One strength is the clear grounding of the caring exemplifiers in existing theory, and the rigorous way in which the final group of teachers was identified. Although the sample size is very small, transfer of the study in so far as it provides sufficient detail in order that other subsequent researchers may determine the utility of the 
findings for their own research is an important element of this research. Related to this, was another and significant strength of this research, by virtue of its acknowledgement of the entanglement of 'caring teaching' with the construct of the 'caring teacher'. The findings illustrate richly that these academics' constructions of themselves as caring teachers combine the principled, the practical and the discursive, and that their visible recognition as a 'caring teacher' was subject to constant inner clarifications and qualifications about who they were, who they thought they should be, and how they thought they should be acting. Such findings shed light on the significance of the exemplifiers as theoretical grounding frameworks, and question their solidity as useful concepts within caring higher education contexts. Another research strength concerned the coding procedure, in particular the semantic sensitivity and the intensive time investment in faithfully representing codes by particular terms spoken by the participants and the subtle way in which thiswas congruent with the complexity of caring research. Teachers and academics may well behave consistently in such a way and carry out their work with what appears to be a form of particular social relations so being perceived by others to be a caring teacher, yet holding no particular system of beliefs that identifies relational pedagogy as being significant to themselves as individuals (Goldstein \& Lake, 2003).

Consequently, a major issue

for any research attempting to capture the inner lives of caring teachers concerns fidelity and validity: the relationships between contextual and intervening categories in this study clearly expose the claims and refutations surrounding these teachers' care. Weaknesses of the study include the fact that in such a small sample, however ultimately purposive and valid, we risked contriving to make the sub-categories more apparent, through separating them when in reality the teachers' testimonies were complex, and ideas and concepts overlapped. Also, it could be argued that we set out to justify our theoretical framework in advance through the use of the caring exemplifiers: sharing these with the participants increased the possibility of disclosing more intervening sub-categories. However, we justify this on the basis that the clear grounding of theory, and the fact that repeated interviewing gave participants much opportunity to defend inclusion of data in particular categories. Furthermore, we acknowledge the fact that our initial positioning of the academics explicitly as 'caring teachers' as functions of others' beliefs rather than letting their espoused behaviors and attributes emerge gradually, may have led them to focus on how different and possibly marginalized they were. However, we maintain that our procedure led to richer insights: presenting the participants with their 'classifications' first, allowed us to proceed without seeming that we were trying to find corroborating evidence of their 'caring', and in addition, such initial exposure as 'caring teachers' gave the participants the remainder of the study's interviews to reflect on the nature of their work more 
subtly and iteratively over time. Despite these weaknesses, this analysis makes an important contribution to theory. To reiterate: there is to our knowledge, no current research that explores the concomitant changes that may possibly occur in higher education teachers' pedagogies amongst those who persist in espousing and enacting pedagogic care as a function of personal belief and ethic. It is in this context that the study offers a unique perspective on caring teachers in practice.

The central concept that appeared to stand behind all others togetherwas that a caring teacher within higher education places 'a relationship at the centre' and the conceptual narrative was teachers' enduring belief that caring could be enacted through particular forms of relationship and in turn, that it would lead ultimately to more effective learning environments than the ones currently validated within their institution. This is a significant finding considering that there is a dearth of research to link caring with learning outcomes of any kind within higher education (Mariskind, 2014; Zembylas et al., 2014). Nevertheless, the narrative surrounding these teachers' beliefs that students are being empowered, being made intellectually richer because of their particular types of interactions with them, remains very powerful, and agrees with research into students' testimonies that such relationships are precious and valued but costly for both students and academics if they falter (Docan-Morgan, 2011; Hagenauer \& Volet, 2014a). 'A relationship at the centre' seemed also to crystallize ethical beliefs and motivations about the relational nature of teaching and the formation of obligations and morality within the institution (Jennings \& Greenberg, 2009). These beliefs appeared to be operationalized with a high degree of consistency, comprising personal knowledge that signified and symbolized caring ways of working, and so supporting existing literature on studenteacademic relationships as being accepted ways of creating effective learning environments (Hagenauer \& Volet, 2014b).

The constraints on these teachers' beliefs and practices appeared to comprise two elements: personal impediments that resulted from confusions over their roles or feelings, and structural impediments these teachers interpreted actively as boundaries or inducements to operationalize care e concerning being a caring higher education teacher, nothing, it seems, was ambivalent to these academics (L€ahteenoja \& Pirttil€a-Backman, 2005). In this way, the teachers in this study differed from those in school-based studies who 'choose to care' (O'Connor, 2008). The 'compelled to care' category was an explanatory narrative of the relational philosophies of this group of teachers, resting on individual stories and experiences that converged on the compulsion to care as a key element of their construction of themselves as 'caring teachers'. The intervening sub-categories revealed potentially damaging contextual experiences and beliefs that took caring teaching far out of the realm of choice, contradicting existing research in which academics' 
choices appeared to be able to over-ride the potential damaging consequences because they had somehow intellectualized their purpose (Curzon-Hobson, 2002). This study suggests that such existing theory is incomplete: the dichotomy between the centrality of caring above all else and the acute emotions that existed alongside it, was adopted into sophisticated beliefs about caring, and how and whether particular principles could be translated into effective practices that ultimately helped students progress on all educational fronts.

The link between this category and the two other emergent categories, 'caring as resistance' and 'caring as less than', support this strand of the theory, suggesting that in this institution at least, caring pedagogy was frequently misunderstood and a reappraisal of pedagogic practice that deconstructed polarities of cognition-emotion, and intellect-affect, was long overdue (Walker-Gleaves, 2010; Mariskind, 2014). In common with some school-based studies on caring teaching and teachers, there appeared to be a natural discursive environment that construed the caring teacher not as someone who privileged purposeful pedagogic interaction, but as a practice that exemplified deeply entrenched views of institutional relationships that were constructed as deficit or detrimental (Hauver James, 2012), and that this somehow ran contrary to these teachers' pedagogic theories-in-action. This supports Rendon'swork withAmerican faculty who during the course of her research, adopted practices constituting 'pedagogical dissent' (p. 113) in the face of strongly held assumptions about educational practice.

A major finding of the study was the repeated ability of these caring teachers to interpret and translate diverse principles and motivations for caring, into specific practices that encompassed most of the accepted underpinning practices of pedagogic caring, including trust, reciprocity, authenticity, reflexivity, responsiveness and attentiveness. The clearly situated nature of caring was evident in all the teachers, yet the extent of each one being the 'critical' defining caring practice that unequivocally stood behind their 'caring teacher' construct, was unclear. In contrast with existing research into school teachers' caring (Goldstein \& Lake, 2003; Larson \& Silverman, 2005), there seems to be a much greater adherence to specific caring practices within higher education, rather than the adoption of a range of 'caring' attributes into the teachers' identity. Possible reasons for this emerge from the subcategories of 'caring as less than', in which the countering of particular discourses often overshadows particular pedagogic philosophy. This finding exposes the need for future research to explore academics' orientations to care, and to link these with situated pedagogic practices and students' outcomes. In the light of this exposition, Fig. 1 presents an integrative model of the caring teacher in the higher education environment in diagrammatic form. The caring teacher as someone who holds relationships at the centre of their encounters with students is 
accordingly placed at the centre of the diagram. The elements of caring teachers as resistors of discourses, institutional policies, damaging emotional labor, and teachers as unwilling recipients of the impact of being agents of care, surround the relational core, and act as a barrier through which the compulsion to care actively breaks through.

This study advances the understanding of particular teaching practices within higher education. In particular, it focuses on the beliefs and thoughts of caring teachers, providing rich testimony on understanding the role of caring in teaching and learning in universities. Whilst providing original insight into what these 'caring' teachers do and think, it raises important questions about how teachers foster particular relationships and construct particular climates in ways that to them, claim to impact positively on students' academic performance. It is clear though, that contingent and contextual factors impact upon these teachers' ability to practice this 'care', and when academics' personal beliefs become affected by students' behaviors and institutional policies, then integrating care into teacherestudent relationships becomes intensely complex and problematic. As a result, one thing is clear from this research: if caring teaching affects the environment in which students learn within higher education, as well as impacting so clearly upon the teachers practicing this care, then it is a critically important agenda for further research in higher education.

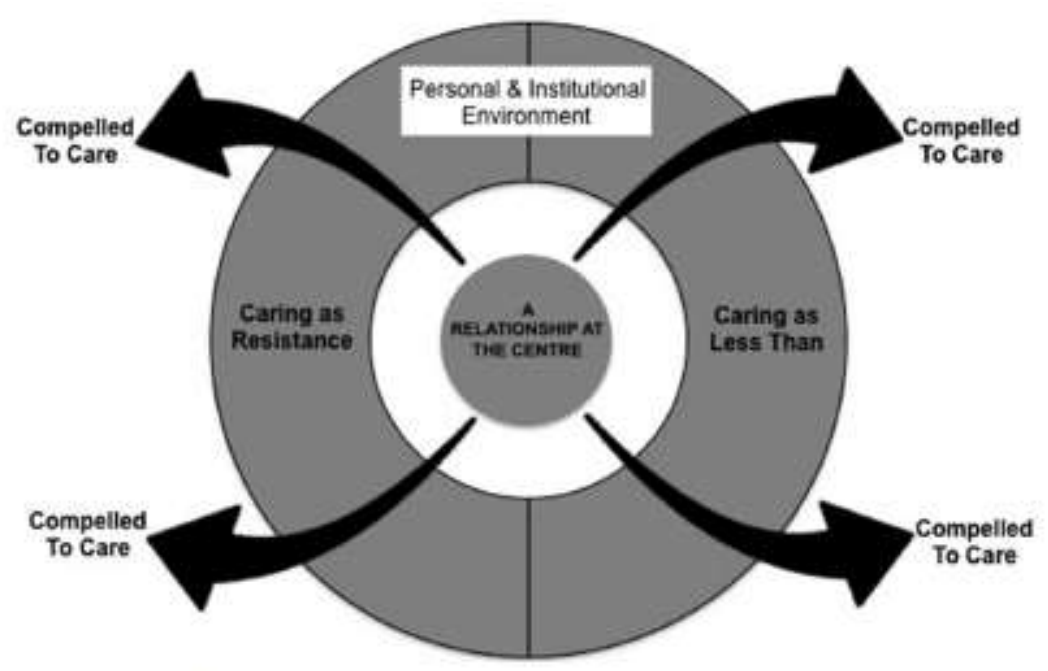

Fig. 1. An integrative model of the caring teacher in higher education.

\subsection{Concluding thoughts}

This study has sought to investigate how perceived caring academics understand and construct caring teaching within higher education. The research was predicated on the perspectives of the teachers themselves, and critically, all were regarded as 'caring' higher education teachers, having been identified through a systematic 
process of reputational case selection grounded rigorously in pedagogic caring theory. Whilst the existing literature on caring teaching suggests that teachers who care are able to impart change touching students personally, socially and academically, affecting students' learning in both cognitive and affective domains, it is only partial literature, and imperfectly theorized, and as such is therefore a potentially critical area of pedagogic research. Furthermore, despite the research evidence on pedagogic caring suggesting that it is fundamental to student and institutional learning outcomes including well-being, achievement and advancement, it seems that, as far as higher education is concerned, there is limited evidence for institutions and many academics to claim that teachers who enact pedagogic care are either purposeful in their intentions or efficacious in their outcomes. This study contributes to the literature on pedagogic caring in higher education, but it has its limitations, particularly in the realm of generalizability. The study was carried out at one institution, within a particular cultural and philosophical environment, and in a particular economic climate within the UK of increasing austerity and accountability of resources. Further research would be situated at other universities with different academic and social aims and missions, and seek to elucidate the relationship between institutional fees policy and academic research and teaching practices. In particular, methodological approaches utilizing quantitative and modeling methods that take into account teacher-related variables such as disciplinary background, teaching style, teaching experience outside higher education could be adopted.

\section{References}

Agne, K. J. (1992). Caring: the expert teacher's edge. Educational Horizons, 70(3), $120 \mathrm{e} 124$.

Artino, A. R., Hemmer, P. A., \& Durning, S. J. (2011). Using self-regulated learning theory to understand the beliefs, emotions, and behaviors of struggling medical students. Academic Medicine, 86, S35eS38.

Walker-Gleaves, C. (2010). Invisible threads of pedagogic care: a study of 'caring' academics and their work within a UK university. Saarbrucken: LAP-Verlag. Walker, C., Gleaves, A., Grey, J., et al. (2006). A study of the difficulties of care and support in New University Teachers' work. Teachers and Teaching: Theory and Practice, 12(3), 347e363.

Barber, T. (2002). A special duty of care: exploring the narration and experience of teacher caring. British Journal of Sociology of Education, 23(3), 383e395.

Bergin, C., \& Bergin, D. (2009). Attachment in the classroom. Educational Psychology Review, 21, 141e170.

Charmaz, K. (1995). Grounded theory. In J. A. Smith, R. Harre, \& L. Van Langenhove (Eds.), Rethinking methods in psychology (pp. 27e49). London: Sage.

Coe, R., Aloisi, C., Higgins, S., \& Major, L. E. (2014). What makes great teaching? A review of the underpinning research. London: Sutton Trust.

Council for the Advancement of Standards. (2006). CAS characteristics of individual excellence for professional practice in higher education. In Council for the Advancement of Higher Education (Ed.), CAS professional standards for higher education (6th ed.). Washington, DC: CAS. 
CSTP (California Standards for the Teaching Profession). (2009). Commission on teacher credentialling. Retrieved June 21, from: http://www.ctc.ca.gov/educatorprep/ standards/CSTP-2009.pdf.

Curzon-Hobson, A. (2002). A pedagogy of trust in higher education. Teaching in Higher Education, 7(3), 265e276.

Dallavis, C. (2014). Culturally responsive caring and expectations for academic achievement in a catholic school. Catholic Education: A Journal of Inquiry and Practice, 17(2), 154e171.

Deakin Crick, R., McCombs, B., \& Haddon, A. (2007). The ecology of learning: factors contributing to learner centred classroom cultures. Research Papers in Education, 22(3), 267 e307.

DeMarrais, K., \& Tisdale, K. (2002). What happens when researchers inquire into difficult emotions? Reflection on studying women's anger through qualitative interviews. Educational Psychology, 37(2), 115e123.

DfE (Department for Education). (2013). Guidance on teachers' standards. Retrieved April 10, from: https://www.gov.uk/government/publications/teachersstandards. Docan-Morgan, T. (2011). 'Everything changed': relational turning point events in college teacherestudent relationships from teachers' perspectives. Communication Education, 60, 20e50.

Edwards, A., \& D'Arcy, C. (2004). Relational agency and disposition in sociocultural accounts of learning to teach. Educational Review, 56(2), 147e155.

Ferreira, M. M., \& Bosworth, C. (2001). Defining caring teachers: adolescents' perspectives. The Journal of Classroom Interaction, 36(1), 24e30.

Fitzmaurice, M. (2008). Voices from within: teaching in higher education As a moral practice. Teaching In Higher Education, 13(3), 341e352.

Gay, G. (2010). Culturally responsive teaching: theory, research and practice. New York: Teachers' College Press.

Glaser, B. G. (1978). Theoretical sensitivity: advances in the methodology of grounded theory. Mill Valley, CA: Sociology Press.

Glaser, B. G., \& Strauss, A. (1967). The discovery of grounded theory: strategies for qualitative research. New York: Aldine de Gruyter.

Goldstein, L. (1999). The relational zone: the role of caring in the co-construction of mind. American Educational Research Journal, 36(3), 647e673.

Goldstein, L. S., \& Lake, V. E. (2003). The impact of field experience on preservice teachers' understandings of caring. Teacher Education Quarterly, 30(3), 115e132. Hagenauer, G., \& Volet, S. E. (2014a). Teacher-student relationship at university: an important yet under-researched field. Oxford Review of Education, 40(3), $370 \mathrm{e} 388$.

Hagenauer, G., \& Volet, S. E. (2014b). 'I don't think I could, you know, just teach without any emotion': exploring the nature and origin of university teachers' emotions. Research Papers in Education, 29, 240e262.

Harley, S. (2003). Research selectivity and female academics in U. K. Universities: from Gentleman's club and Barrack Yard to smart Macho? Gender and Education, 15(4), 377e392.

Hattie, J. (2003). Teachers make a difference: distinguishing expert teachers from novice and experienced teachers. In Paper presented at the Australian Council for Educational Research, University Of Auckland, October 2003.

Hauver James, J. (2012). Caring for "others": examining the interplay of mothering and deficit discourses in teaching. Teaching and Teacher Education, 28(2), $165 \mathrm{e} 173$.

Higher Education Academy (HEA). (2013). UK professional standards framework. 
Retrieved May 16, from: https://www.heacademy.ac.uk/recognitionaccreditation/ uk-professional-standards-framework-ukpsf.

Hixenbaugh, P., \& Thomas, L. (2006). Personal tutoring in higher education. London: Trentham Books.

Husbands, C., \& Pearce, J. (2012). What is great pedagogy: A literature review for the national College of school leadership. London: National College for School Leadership.

James, M., \& Pollard, A. (2011). TLRP's ten principles for effective pedagogy: rationale, development, evidence, argument and impact. Research Papers in Education, 26(3), $26 \mathrm{e} 36$.

Jennings, P. A., \& Greenberg, M. T. (2009). The prosocial classroom: teacher social and emotional competence in relation to student and classroom outcomes.

Review of Educational Research, 79(1), 491e525.

Kyriakides, L., Creemers, B. P. M., \& Antoniou, P. (2009). Teacher behaviour and student outcomes: suggestions for research on teacher training and professional development. Teaching and Teacher Education, 25, 12e23.

L€ahteenoja, S., \& Pirttil€a-Backman, A.-M. (2005). Cultivation or coddling? University teachers' views on student integration. Studies in Higher Education, 30, 641e661. Larson, A. (2006). Student perception of caring teaching in physical education. Sport, Education and Society, 11(4), 337e352.

Larson, A., \& Silverman, S. J. (2005). Rationales and practices used by caring physical education teachers. Sport, Education and Society, 10(2), 175e193.

Leathwood, C., \& Read, B. (2009). Gender and the changing Face of higher education: A feminised future? Maidenhead: McGraw-Hill/Open University Press.

LeCompte, M. D., \& Preissle, J. (1993). Ethnography and qualitative design in Educational research (2nd ed.). San Diego: Academic Press.

Lippke, L. (2012). "Who am I supposed to let down?": the caring work and emotional practices of vocational educational training teachers working with potential drop-out students. Journal of Workplace Learning, 24(7/8), 461e472. Mariskind, C. (2014). Teachers' care in higher education: contesting gendered constructions. Gender and Education, 26(3), 306e320.

McCormick, M., O'Connor, E. E., Cappella, E., \& McClowry, S. (2013). Teacherechild relationships and academic achievement: a multi-level propensity score model approach. Journal of School Psychology, 51, 611e624.

McCuaig, L. A. (2012). Dangerous carers: pastoral power and the caring teacher of contemporary Australian schooling. Educational Philosophy and Theory, 44(8), $862 \mathrm{e} 877$.

Monzo, L. D., \& Rueda, R. S. (2001). Professional roles, caring, and scaffolds: Latino teachers' and paraeducators' interactions with Latino students. American Journal of Education, 109(4), 438e471.

Morley, L., \& Lugg, R. (2009). Mapping meritocracy: intersecting gender, poverty and higher educational opportunity structures. Higher Education Policy, 22(1), 37 e60.

Muller, C. (2001). The role of caring in the teacher-student relationship for at-risk students. Sociological Inquiry, 71(2), 241e255.

New Zealand Education Council. (2015). Practising teacher criteria. Retrieved 5 June 2015, from: http://www.educationcouncil.org.nz/content/registered-teachercriteria1.

Noddings, N. (1986). Fidelity in teaching, teacher education, and research for teaching. Harvard Educational Review, 56(4), 496e510.

Noddings, N. (2003). Happiness and education. Cambridge: Cambridge University 
Press.

Nowak-Fabrykowski, T. K. (2012). An analysis of caring behaviour among early childhood teachers and children. Early Child Development and Care, 182(9), $1185 \mathrm{e} 1192$.

O'Connor, K. E. (2008). 'You choose to care': teachers, emotions and professional identity. Teaching and Teacher Education, 24(1), $117 e 126$.

Ravizza, D. M., \& Stratton, R. K. (2007). Students' perceptions of physical education teacher's caring. Research Quarterly for Exercise and Sport Science, 78, 70e72. Rendon, L. I. (1994). From the Barrio to the academy: revelations of a Mexican American "scholarship girl." In S. L. Zwerling, \& H. B. London (Eds.), First generation students: Confronting the cultural issues (pp. 55e64). San Francisco:

Jossey-Bass.

Rendon, L. I. (2009). Sentipensante (sensing/thinking) pedagogy: Educating for wholeness, social justice and liberation. Sterling, VA: Stylus.

Rivera-McCutchen, R. L. (2012). Caring in a small urban high school: a complicated success. Urban Education, 47(3), $653 e 680$.

Robson, J., \& Bailey, B. (2009). 'Bowing from the heart': an investigation into discourses of Professionalism and the work of caring for students, professionalism and the work of caring for students in further education. British Educational Research Journal, 35(1), 99e117.

Rossman, G., \& Rallis, S. (2003). Learning In The Field: An introduction to qualitative research (2nd ed.). Thousand Oaks, CA: Sage.

Rudasill, K. M. (2011). Child temperament, teacherechild interactions, and teacherechild relationships: a longitudinal investigation from first to third grade.

Early Childhood Research Quarterly, 26, 147e156.

Sawatzky, J. V., Enns, C., Ashcroft, T. J., Davis, P. L., \& Harder, B. N. (2009). Teaching excellence In Nursing Education: A caring framework. Journal of Professional Nursing, 25(5), 260e266.

Seidman, I. (1998). Interviewing as qualitative research: A guide for researchers in education and the social sciences. New York: Teachers College Press.

Strauss, A. L., \& Corbin, J. (1990). Basics of qualitative research: Grounded theory procedures and techniques. London: Sage Publications.

Strauss, A. L., \& Corbin, J. (1998). Basics of qualitative research: techniques and Procedures for Developing Grounded Theory. London: Sage Publications.

Task Force for Teaching Excellence. (2014). Part 1: Report to the minister of education, government of Alberta. Retrieved 1 April 2015, from: https://inspiring.education. alberta.ca/wpcontent/themes/part1/_documents/GOAE_ TaskForceforTeachingExcellence_WEB_updated.pdf. Thayer-Bacon, B., \& Bacon, C. S. (1996). Caring professors: a model. The Journal of General Education, 45(4), $255 \mathrm{e} 256$.

Velasquez, A., West, R., Graham, C., \& Osguthorpe, R. (2013). Developing caring relationships in schools: a review of the research on caring and nurturing pedagogies. Review of Education, 1(2), 162e190.

Wentzel, K. R. (1997). Student motivation in middle school: the role of perceived pedagogical caring. Journal of Educational Psychology, 89(3), 411e419.

Weston, C., \& McAlpine, L. (1998). How six outstanding mathematics professors view teaching and learning: the importance of caring. International Journal of Academic Development, 3(2), $146 \mathrm{e} 155$.

Wilcox, P., Winn, S., \& Fyvie-Gauld, M. (2005). 'It was nothing to do with the university, it was just the people': the role of social support in the first-year experience of higher education. Studies in Higher Education, 30, 707e722. 
Zembylas, M., Bozalek, V., \& Shefer, T. (2014). Tronto's notion of "privileged irresponsibility" and the reconceptualisation of care: implications for critical

pedagogies of emotion in higher education. Gender and Education, 26(3),

$200 \mathrm{e} 214$.

Zepke, N., \& Leach, L. (2010). Beyond hard outcomes: 'soft' outcomes and engagement as student success. Teaching in Higher Education, 15, 661e673. 